\title{
THE EFFECT OF AGRONOMIC AND CLIMATIC FACTORS ON WINTER OILSEED RAPE (BRASSICA NAPUS L.) ROOT NECK GROWTH IN AUTUMN
}

Gvidas ŠIDLAUSKAS, Institute of Agroecosystem and Soil Sciences, Faculty of Agronomy, Aleksandras Stulginskis University, Studentų g. 11, Akademija LT-53361, Kauno r. sgvidas@gmail.com

Irena PRANCKIETIENE், Institute of Agroecosystem and Soil Sciences, Faculty of Agronomy, Aleksandras Stulginskis University, Studentu g. 11, Akademija LT-53361, Kauno r. irena.pranckietiene@asu.lt (corresponding author)

Rūta DROMANTIENÉ, Institute of Agroecosystem and Soil Sciences, Faculty of Agronomy, Aleksandras Stulginskis University. Studentų g. 11, Akademija LT-53361, Kauno r. ruta.dromantiene@asu.lt

Viktoras PRANCKIETIS, Institute of Agricultural and Food Sciences, Faculty of Agronomy, Aleksandras Stulginskis University. Studentų g. 11, Akademija LT-53361, Kauno r. viktoras.pranckietis@asu.lt

\begin{abstract}
The aim of this study was to investigate the growth habit of winter oilseed rape root neck during the vegetative period in autumn Such information is important for better understanding of winter oilseed rape growth pattern at early stages of development with the purpose to improve over winter survival. Field trials were conducted on Endocalcari - Epihypogleyic Cambisols. For the determination of changes of winter oilseed rape root neck thickness during autumnal development the effect of planting date, seedbed nitrogen application, stand population density, number of calendar days after emergence, accumulated by plants growing degree days and interaction among these factors was tested. For the description of the root neck growth pattern Boltzmann's growth function performing a nonlinear fitting of estimating parameters was used. Results collected in the experiments indicate that the effect of sowing date including accumulated by plants growing degree days and the number of calendar days after emergence showed much greater effect on winter oilseed rape root diameter than seeding rate or pre-plant nitrogen application. On the basis of collected data winter oilseed rape root neck growth model was developed. These studies that relate mentioned factors to fall growth of winter oilseed rape root neck are presented in the paper.
\end{abstract}

Keywords: growing degree days, number of calendar days, nitrogen application, stand population density.

\section{INTRODUCTION}

Oilseed rape is an important crop in countries with cooler climates, providing a break in cereal dominated rotations. The highest yields of oilseed rape are achieved with optimum sowings on highly fertile sites, or with sophisticated management techniques (Johnson, 2004; Burton et al., 2003). However, the yield of oilseed rape is rather low and unstable in |Lithuania as compare to countries with similar soils and climatic conditions. Such a situation is accentuating the need to investigate the growth and development patterns particularly of winter oilseed rape during the vegetative growth in autumn. Major improvements in over winter survival as well as seed yield could be achieved by creating optimal growth and development conditions for winter oilseed rape. It was showed that before inflorescence is initiated, the plants must reach a critical size. Below this optimal size, seed yield is diminished proportionately and above this size, there is no extra yield because of other limiting factors (Mendham and Scott, 1995). This critical size may be expressed with plant dry weight, leaf area, leaf number per plant, root neck thickness or other indices, and it may differ with genotype and season (Mendham and Salisbury, 1995). Agronomic practices including sowing date, seeding rate or nitrogen fertilization also had an effect on winter oilseed rape growth and development. Observations of winter oilseed rape root neck thickness showed that plants with a root diameter of $4 \mathrm{~mm}$ or less had $98 \%$ mortality during the winter (Pietola, 2005). Survival was the highest when winter oilseed rape plants had root neck diameter of 5 $-16 \mathrm{~mm}$, and a stem elongation in the $0-30 \mathrm{~mm}$ range at the end of vegetative growth period in autumn. The damage during winter was most frequently observed in plants with longer stems. To withstand periods of temperatures below freezing, plants should reach the 6-8 true-leaf stage, have a root head diameter of $>5 \mathrm{~mm}$ and a shoot length of < 20 mm (Diepenbrock, 2000; Schröder and Makowski, 1996).

French studies showed that, in order to obtain optimum winter oilseed rape growth before winter, a period is required with accumulated temperatures of $600-800{ }^{\circ} \mathrm{C}$ (above $0{ }^{\circ} \mathrm{C}$ ) from emergence to the first frost with above 60 plants $\mathrm{m}^{-2}$ (Pouzet, 1995). So the analyses of annual climatic statistics and winter oilseed rape growth pattern can

Copyright (c) 2015 The Authors. Published by Aleksandras Stulginskis University. This is an open-access article distributed under the terms of the Creative Commons Attribution License (CC-BY 4.0), which permits unrestricted use, distribution, and reproduction in any medium, provided the original author and source are credited. 
help in determining the optimal date of sowing and improving over winter survival especially where cultivation of winter oilseed rape is limited by its cold resistance and plant losses are severe in bad winters.

The objectives of this study were to investigate how the root neck thickness of winter oilseed rape plant during the vegetative growth in autumn was controlled by air temperature, number of calendar days after emergence, pre-plant nitrogen application and stand population density under the local climatic and soil conditions as well as the interaction among these factors. This information should add to the understanding of the physiology of the crop as well as indicating whether such treatments are likely to be useful in improving winter oilseed rape over winter survival and increasing the potential for consistent yields.

\section{MATERIALS AND METHODS}

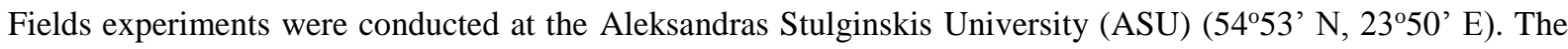
soil of the experimental site is glacial lacustrine loam on moraine loam Endocalcari - Epihypogleyic Cambisols. Soil test revealed from 0.15 to $0.18 \%$ of total nitrogen, $258-297 \mathrm{mg} \mathrm{kg}^{-1}$ soil $\mathrm{P}_{2} \mathrm{O}_{5}, 155-177 \mathrm{mg} \mathrm{kg}^{-1}$ soil K$_{2} \mathrm{O}$ and $1.23 \%$ of total carbon in the arable layer. The $\mathrm{pH}$ ranged between 6.7 and 7.2 when measured in $1 \mathrm{~N} \mathrm{KCl}$. Single granular superphosphate $\left(90 \mathrm{~kg} \mathrm{ha}^{-1} \mathrm{P}_{2} \mathrm{O}_{5}\right)$ and potassium chloride $\left(120 \mathrm{~kg} \mathrm{ha}^{-1} \mathrm{~K}_{2} \mathrm{O}\right)$ were broadcasted at seeding. For treatments with pre-plant nitrogen fertilization $30 \mathrm{~kg} \mathrm{ha}^{-1}$ of ammonium nitrate was applied.

Fully randomized complete block design with three replicates consisted of a factorial combination of three sowing dates, three seed rates and two pre-plant nitrogen application rates were used in the experiment. Oilseed Rape (Brassica napus) were seeded with a $12.5 \mathrm{~cm}$ interrow spacing at three seeding dates (late July - early August, mid and late August). Moreover, three seeding rates (3, 6 and $9 \mathrm{~kg} \mathrm{ha}^{-1}$ ). First seeding date depended on soil and weather conditions. Second and third seeding date was delayed until fully emergence of the previous seeding but the duration between seeding dates was not less than 10-14 calendar days.

Ten plant samples were collected from each plot every week starting with emergence and until the fall growth had ceased in the late October - early November for the measurements of the dimension of winter oilseed rape root neck thickness. Root neck diameter was measured under the cotyledon scars for each plant. Weather data was obtained from the Agrometeorological station on the site. The baseline temperature used for growing degree days (GDD) computations was $5{ }^{\circ} \mathrm{C}$. Boltzmann's growth model as well as regression and correlation methods were used for data statistical analyses performed with Statistica software (Statistica System Reference, 2001) (Hill and Levicki, 2005). * - significant at $\mathrm{P} \leq 0.05 \%$ and ${ }^{* *}$ - significant at $\mathrm{P} \leq 0.01 \%$.

\section{RESULTS AND DISCUSSION}

\section{Planting date}

For the general presentation of the winter oilseed rape root neck growth pattern during the vegetative growth period in fall 2009 was chosen as the most typical year. Growth stages of the first sowing date, sampling dates, number of calendar days after emergence accumulated by plants GDD and changes in root neck thickness during the vegetative growth period in autumn of 2009 are presented in Table 1.

Table 1. Growth stages, date of sampling, root neck thickness, number of calendar days after emergence (CD) and accumulated growing degree days (GDD, $>5^{\circ} \mathrm{C}$ ) by plants in 2009

\begin{tabular}{|c|c|c|c|c|c|c|}
\hline \multirow{2}{*}{$\begin{array}{l}\text { Growth } \\
\text { stage* }\end{array}$} & \multirow{2}{*}{$\begin{array}{c}\text { Date } \\
\text { sampled }\end{array}$} & \multirow{2}{*}{$\begin{array}{l}\text { CD } \\
\text { (d) }\end{array}$} & \multirow{2}{*}{$\begin{array}{l}\text { GDD } \\
\left({ }^{\circ} \mathrm{C} . \mathrm{d}\right)\end{array}$} & \multicolumn{3}{|c|}{ Root neck thickness (mean, mm) } \\
\hline & & & & sown July 24 & sown August 05 & sown August 18 \\
\hline 1.0 & Aug.03 & 2 & 42.6 & 1.0 & - & - \\
\hline $1.1-1.2$ & 10 & 9 & 123.1 & 1.0 & - & - \\
\hline $1.3-1.4$ & 17 & 16 & 193.6 & 2.0 & 1.0 & - \\
\hline $1.4-1.5$ & 24 & 23 & 263.4 & 2.7 & 1.5 & 1.0 \\
\hline $1.5-1.6$ & 31 & 30 & 310.8 & 3.3 & 2.0 & 1.0 \\
\hline $1.7-1.8$ & Sep.07 & 37 & 353.0 & 4.3 & 2.1 & 1.0 \\
\hline $1.8-1.9$ & 14 & 44 & 432.2 & 6.3 & 2.6 & 1.7 \\
\hline $1.9-1.10$ & 21 & 51 & 476.1 & 7.3 & 3.2 & 2.2 \\
\hline $1.11-1.12$ & 28 & 58 & 522.6 & 9.0 & 4.1 & 2.8 \\
\hline $1.12-1.13$ & Oct.05 & 65 & 527.7 & 9.9 & 4.6 & 3.0 \\
\hline $1.13-1.14$ & 12 & 72 & 541.8 & 11.8 & 6.0 & 3.5 \\
\hline $1.14-1.15$ & 18 & 79 & 564.3 & 11.7 & 9.0 & 3.6 \\
\hline $1.15-1.16$ & 26 & 86 & 588.0 & 11.9 & 8.8 & 4.2 \\
\hline
\end{tabular}

* From Sylvester - Bradley \& Makepeace, 1984

- Not sampled

Winter oilseed rape was sown on July 24, August 05 and 18. From emergence till the end of vegetative growth in autumn 86, 74 and 63 calendar days had passed accordingly. Winter oilseed rape plants sown at the end of July accumulated 588.0 ${ }^{\circ} \mathrm{C}$ GDD. Meanwhile, plants sown in early August accumulated 451.0 ${ }^{\circ} \mathrm{C}$ GDD and those sown on the latest date accumulated $331.9^{\circ} \mathrm{C}$ GDD. Winter oilseed rape root neck thickness was strongly affected by sowing 
date expressed in the number of calendar days or accumulated by plants GDD. Root diameter in the stand of the earliest planting date on average reached $12.1 \mathrm{~mm}$ at the end of vegetative growth period in autumn. Meanwhile, the root neck thickness increase up to $8.8 \mathrm{~mm}$ in the mid planting stand. The thinnest root diameter $-4.2 \mathrm{~mm}$ was observed in the stand of the latest sowing. The response of root neck thickness to sowing date was similar to that seen previously where the root neck diameter increased from $2.9 \mathrm{~mm}$ when planted in the mid of September to $16.8 \mathrm{~mm}$ in the first of August sown treatment (Topinka et al., 1991).

In other experiment was found that heterosis occurred at all stages of development therefore hybrids had $11 \%$ more above-ground biomass in autumn, $8 \%$ more biomass at maturity and $25 \%$ more dry matter after flowering compare to their parents, indicating that major processes involved in the formation of yield are more effective in hybrid varieties (Diepenbrock, 2000; Grosse et al., 1992). Changes in root neck thickness of Brassica napus with time are shown in Fig.1. According to the collected data root neck thickness has very strong correlation with the total number of calendar days passed from the emergence till the end of vegetative growth in late fall. The investigations showed that the increase in winter oilseed rape root neck thickness during the first 23 days after emergence was rather negligible in the earliest sown stand.

During that period the diameter of the root neck was increasing on average $0.03-0.15 \mathrm{~mm}$ every day. Starting with the day 24 after emergence or when plants accumulated $270{ }^{\circ} \mathrm{C}$ GDD the root thickness started to expand rapidly. The diameter of the root neck was increasing $0.15-0.22 \mathrm{~mm}$ per day. The maximum growth rate of the root neck thickness $-0.22 \mathrm{~mm}$ per day in the earliest sown stand was observed at day 48 after emergence when plants accumulated $450{ }^{\circ} \mathrm{C}$ GDD. After that the growth rate of root neck became less intensive but the changes in root neck diameter was still clearly obvious until the day 70 (530 ${ }^{\circ} \mathrm{C}$ GDD) after emergence. However, from this point onward to the end of vegetative growth in autumn the changes in root neck thickness became much less obvious $(0.03-0.12 \mathrm{~mm}$ per day). So there three clearly obvious growth periods of winter oilseed rape root neck thickness in the earliest sown plots were observed. Such growth pattern of winter oilseed rape root diameter (earliest sown - ys1) during the vegetative growth period in autumn was expressed with Boltzmann's growth model:

$$
y_{S 1}=a+\frac{-b}{1+e^{\left(\frac{x-c}{d}\right)}} ;
$$

$\mathrm{R}=0.997^{* *}$, with $\mathrm{a}=12.91 \mathrm{~mm}, \mathrm{~b}=12.36 \mathrm{~mm}, \mathrm{c}=47.27 \mathrm{~d}, \mathrm{~d}=14.02 \mathrm{~d}$, if $y_{\mathrm{S} 1}$ is expressed in $\mathrm{mm}$.

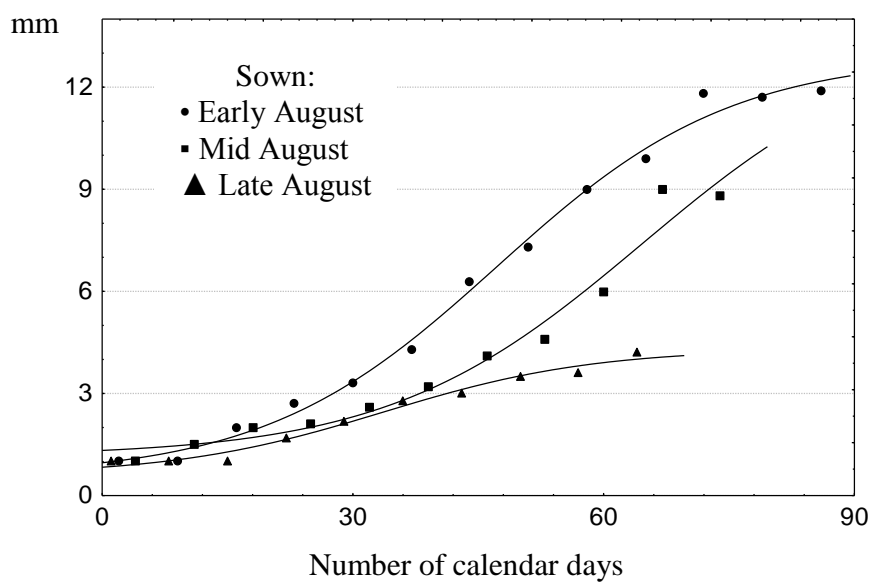

Figure 1. The relationship between winter oilseed rape root neck thickness and the number of calendar days after emergence in autumn

The growth pattern of the winter oilseed rape root neck diameter of the mid sown stand was different. In this case there were only two clearly obvious periods of changes in the root neck thickness. During the first 37 calendar days after emergence the increase in root neck diameter was slow $-0.01-0.09 \mathrm{~mm}$ per day. Up to this point winter oilseed rape plants accumulated approximately $300{ }^{\circ} \mathrm{C}$ GDD. Starting with the day 38 onward to the end of vegetative growth period the diameter of the root neck was increasing rapidly $-0.1-0.21 \mathrm{~mm}$ per day. There was not noticed the decrease in root neck thickness growth rate in the mid sown winter oilseed rape stand at the end of vegetative growth in autumn as it was noticed in the earliest sown stand. The relationship between root neck thickness and the number of calendar days after emergence in the mid planted stand was described by sigmoidal curve:

$$
y_{S 2}=a+\frac{-b}{1+e^{\left(\frac{x-c}{d}\right)}} ;
$$

$\mathrm{R}=0.986^{* *}$, with $\mathrm{a}=13.64 \mathrm{~mm}, \mathrm{~b}=12.49 \mathrm{~mm}, \mathrm{c}=64.59, \mathrm{~d}=15.19 \mathrm{~d}$, if $y_{\mathrm{S} 1}$ is expressed in mm. 
Due to much lower air temperatures the growth of the root neck during the vegetative growth period in autumn in the latest sown winter oilseed rape stand was much less intensive as compare to both earlier sown stands especially in the second part of vegetative growth period. Such growth pattern resulted in the thinnest root neck at the end of vegetative growth period. Some negligible increase in root neck thickness growth rate per day was noticed at the day 15 after emergence. Up to this pint plants accumulated $100{ }^{\circ} \mathrm{C}$ GDD. When plants accumulated $270{ }^{\circ} \mathrm{C}$ GDD or 45 calendar days have passed from emergence the root neck growth rate was slowing down again. So there were noticed three root neck growth periods in the latest sown winter oilseed rape stand. However, these periods were much less obvious as they were in the earliest sown stand. Changes in root neck thickness with time were expressed with sigmoidal curve:

$$
y_{S 3}=a+\frac{-b}{1+e^{\left(\frac{x-c}{d}\right)}} ;
$$

$\mathrm{R}=0.991^{* *}$, with $\mathrm{a}=4.31 \mathrm{~mm}, \mathrm{~b}=3.72 \mathrm{~mm}, \mathrm{c}=33.63 \mathrm{~d}, \mathrm{~d}=12.58 \mathrm{~d}$, if $y_{\mathrm{S} 1}$ is expressed in $\mathrm{mm}$.

Thus according to the data obtained it is clear that the increase in winter oilseed rape root neck thickness is depending on the number of calendar days after emergence as well as the air temperature. Using Boltzmann's sigmoidal equation strong relationship between winter oilseed rape root neck thickness and accumulated by plants GDD was found in the experiment. For the earliest sowing date the relationship was expressed as:

$$
y_{S 1}=a+\frac{-b}{1+e^{\left(\frac{x-c}{d}\right)}} ;
$$

$\mathrm{R}=0.993^{* *}$; with $\mathrm{a}=23.91 \mathrm{~mm}, \mathrm{~b}=23.37 \mathrm{~mm}, \mathrm{c}=582.68^{\circ} \mathrm{C} . \mathrm{d}, \mathrm{d}=135.29^{\circ} \mathrm{C} . \mathrm{d}$, if $y_{\mathrm{S} 1}$ is expressed in $\mathrm{mm}$.

for the mid sowing date:

$$
y_{S 2}=a+\frac{-b}{1+e^{\left(\frac{x-c}{d}\right)}} ;
$$

$\mathrm{R}=0.978^{* *}$; with $\mathrm{a}=9.43 \mathrm{~mm}, \mathrm{~b}=7.4 \mathrm{~mm}, \mathrm{c}=399.99^{\circ} \mathrm{C} . \mathrm{d}, \mathrm{d}=15.23{ }^{\circ} \mathrm{C} . \mathrm{d}$, if $y_{\mathrm{S} 2}$ is expressed in $\mathrm{mm}$.

and for the latest sowing date relationship was expressed as:

$$
y_{S 3}=a+\frac{-b}{1+e^{\left(\frac{x-c}{d}\right)}} ;
$$

$\mathrm{R}=0.996^{* *}$; with $\mathrm{a}=6.08 \mathrm{~mm}, \mathrm{~b}=5.22 \mathrm{~mm}, \mathrm{c}=294.61{ }^{\circ} \mathrm{C} . \mathrm{d}, \mathrm{d}=68.24{ }^{\circ} \mathrm{C} . \mathrm{d}$, if $y_{\mathrm{S} 3}$ is expressed in $\mathrm{mm}$.

The formulas beneath describe the influences of total number of calendar days as well as accumulated by plants GDD passed from the emergence till the end of vegetative growth in late fall on winter oilseed rape root neck thickness during the vegetative growth period in autumn with the accuracy of $98.8-99.6 \%$.

$$
Y_{d}=y_{\mathrm{S} 1}+y_{\mathrm{S} 2}+y_{\mathrm{S} 3} ; \mathrm{R}=0,988 * * \quad Y_{G D D}=y_{\mathrm{S} 1}+y_{\mathrm{S} 2}+y_{\mathrm{S} 3} ; \mathrm{R}=0,994 * *
$$

\section{Nitrogen application}

Applying autumn nitrogen to winter oilseed rape is common practice in North East Europe. Authors who have measured the effects of different autumn nitrogen supplies on winter oilseed rape autumn growth such as aerial biomass, leaf area index, photosynthetic activity have shown that tap root biomass is important for aerial growth rate in early spring (Kamh, 2005; Colnenne et al., 2002; Mendham, 1995). However, although plants receiving nitrogen in seedbed or at the two - three leaf stage appeared to be more vigorous before winter compared with unfertilized plants, neither the number of plants established, survival over winter, nitrogen uptake by seed, apparent N-use efficiency, nor seed yield appeared to be affected by this treatment (Sieling et al., 1998). Despite that autumnal nitrogen application increased winter oilseed rape leaf area index and plant dry weight (Colnenne et al., 2002; Cheema et al., 2001). However, there was no significant effect on winter oilseed rape root neck thickness during the vegetative growth period in autumn when $30 \mathrm{~kg} \mathrm{ha}^{-1}$ of nitrogen was applied at sowing (Fig. 2). The changes in winter oilseed rape plant root diameter for the first 60 days after emergence were almost the same in treatments with and without nitrogen application. 
$\mathrm{mm}$

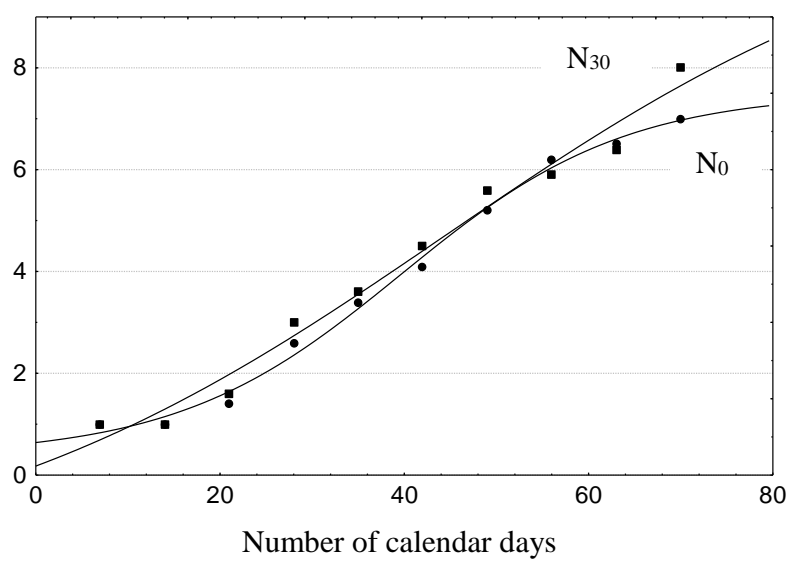

Figure 2. The influence of nitrogen application on winter oilseed rape root neck thickness during the vegetative growth in autumn

However, from this point onward some rather small differences in root neck thickness became noticeable. It appeared that pre-plant nitrogen application slightly tended to increase the diameter of winter oilseed rape root neck. The differences became the most obvious at the end of vegetative growth period in early November. It could be possible that pre-sowing nitrogen application firstly positively affected winter oilseed rape dry weight, leaves growth and plant leaves area especially in earlier sown stands. The increase in plant leaves area resulted in stronger competition among individual plants which effect was the most obvious on shoot length. Meanwhile, nitrogen effect on winter oilseed rape root neck thickness was negligible. In spite of that strong relationship between the number of calendar days and root neck thickness was found in both treatments:

$$
y_{N 0}=a+\frac{-b}{1+e^{\left(\frac{x-c}{d}\right)}} ;
$$

$\mathrm{R}=0.982^{* *}$; with $\mathrm{a}=7.51 \mathrm{~mm}, \mathrm{~b}=7.14 \mathrm{~mm}, \mathrm{c}=39.66 \mathrm{~d}, \mathrm{~d}=12.16 \mathrm{~d}$, if $y_{\mathrm{N} 0}$ is expressed in mm.

$$
y_{N 30}=a+\frac{-b}{1+e^{\left(\frac{x-c}{d}\right)}} ;
$$

$\mathrm{R}=0.991^{* *}$; with $\mathrm{a}=11.45 \mathrm{~mm}, \mathrm{~b}=13.49 \mathrm{~mm}, \mathrm{c}=44.45 \mathrm{~d}, \mathrm{~d}=27.34 \mathrm{~d}$, if $y_{\mathrm{N} 30}$ is expressed in $\mathrm{mm}$.

Accumulated by plants GDD during the vegetative growth period in autumn showed very similar and statistically proved effect on winter oilseed rape root neck thickness in treatments with and without pre-plant nitrogen application:

$$
y_{N 0}=a+\frac{-b}{1+e^{\left(\frac{x-c}{d}\right)}} ;
$$

$\mathrm{R}=0.997^{* *}$; with $\mathrm{a}=7.53 \mathrm{~mm}, \mathrm{~b}=6.63 \mathrm{~mm}, \mathrm{c}=409.3^{\circ} \mathrm{C} . \mathrm{d}, \mathrm{d}=61.54{ }^{\circ} \mathrm{C} . \mathrm{d}$, if $y_{\mathrm{N} 0}$ is expressed in mm.

$$
y_{N 30}=a+\frac{-b}{1+e^{\left(\frac{x-c}{d}\right)}} ;
$$

$\mathrm{R}=0.988^{* * *}$; with $\mathrm{a}=9.57 \mathrm{~mm}, \mathrm{~b}=9.04 \mathrm{~mm}, \mathrm{c}=437.9^{\circ} \mathrm{C} . \mathrm{d}, \mathrm{d}=96.3^{\circ} \mathrm{C} . \mathrm{d}$, if $y_{\mathrm{N} 30}$ is expressed in $\mathrm{mm}$.

\section{CONCLUSIONS}

The analysis of winter oilseed rape root neck growth during the vegetative period in autumn revealed that sowing date expressed as accumulated by plants growing degree days or the number of calendar days after emergence showed the strongest effect on root neck thickness. The effect of stand population density on winter oilseed rape root neck growth was weak. With the increase in plant number per $\mathrm{m}^{-2}$ at the end of vegetative growth in autumn by 10 plants the root neck was thinner by $0.162 \mathrm{~mm}$. Pre-plant nitrogen application did not showed any effect on root neck thickness especially for the first 60 days after emergence. From this point onward nitrogen application slightly tended to increase the root neck diameter of winter oilseed rape plant. 


\section{REFERENCES}

1. Burton, W., Salisbury, P., Potts, D. 2003. The potential of canola quality Brassica juncea as an oilseed crop for Australia. In Sorensen, H. (ed) Proceedings of the 11 ${ }^{\text {th }}$ International Rapeseed Congress, Copenhagen, Denmark. 1, pp. 665-670.

2. Cheema, M. A., Malik, M. A., Hussain, A., Shab, S. H., Basra, S. M. A. 2001. Effects of time and rate of nitrogen and phosphorus application on the growth and the seed and oil yields of canola (Brassica napus L.). Journal of Agronomy and Crop Science, Vol. 186, Iss. 2, pp. 103-110. http://dx.doi.org/10.1046/j.1439-037X.2001.00463.x

3. Colnenne, C., Meynard, J. M., Roche, R., Reau, R. 2002. Effects of nitrogen deficiencies on autumnal growth of oilseed rape. European Journal of Agronomy, Vol. 17, Iss. 1, pp. 11-28. http://dx.doi.org/10.1016/S1161-0301(01)00140-X

4. Diepenbrock, W. 2000. Yield analysis of winter oilseed rape (Brassica napus L.): A review. Field Crop Research. Vol. 67, Iss. 1, pp. 35-49. http://dx.doi.org/10.1016/S0378-4290(00)00082-4

5. Grosse, F., Léon, J., Diepenbrock, W. 1992. Ertragsbildung und Ertragsstruktur bei Winterraps (Brassica napus L.). II. Vergleich zwischen Elternlinien und deren F1 - und F2 - Generationen. Journal of Agronomy and Crop Science, Vol. 169, Iss. 1-2, pp. 94103. http://dx.doi.org/10.1111/j.1439-037X.1992.tb01187.X

6. Johnson, E. N., Miller, P. R., Blackshaw, R. E., Gan, Y., Harker, K. N., Clayton, G. W., Kephart, K. D., Wichman, D. M., Topinka, K., Kirkland, K. J. 2004. Seeding date and polymer seed coating effects on plant establishment and yield of fall-seeded canola in the Northern Great Plains. Canadian Journal of Plant Science, Vol. 84, Iss. 4, pp. $955-963$. http://dx.doi.org/10.4141/P04-005

7. Kamh, M., Wiesler, F., Ulas, A., Horst W. J. 2005. Root growth and N-uptake activity of oilseed rape (Brassica napus L.) cultivars differing in nitrogen efficiency. Journal of Plant Nutrition and Soil Science, Vol. 168, Iss. 1, pp.130-137. http://dx.doi.org/10.1002/jpln.200421453

8. Mendham, N. J. 1995. Physiological basis of seed yield and quality in oilseed rape. Proceedings of the $9^{\text {th }}$ International Rapeseed Congress, Cambridge. 2, pp. 485-490.

9. Mendham, N. J., Salisbury, P. A. 1995. Physiology: Crop development, growth and yield. In Kimber, D \& McGregor, D.I. (ed) Brassica Oilseeds. Production and utilization. CAB International, pp. 11-64.

10. Pietola, L., Alakukku, L. 2005. Root growth dynamics and biomass input by Nordic annual field crops. Agriculture, Ecosystems \& Environment, Vol. 108, Iss. 2, pp. 135-144. http://dx.doi.org/10.1016/j.agee.2005.01.009

11. Pouzet, A. 1995. Agronomy. In Kimber, D \& McGregor, D.I. (ed) Brassica Oilseeds. Production and utilization. CAB International, pp. 65-92.

12. Schröder, G., Makowski, N. 1996. Betrachtungen zur Ertragsbildung bei Winterraps. Archiv für Acker- und Pflanzenbau und Bodenkunde, Vol. 40, pp. 175-181.

13. Sieling, K., Schröder, H., Hanus, H. 1998. Mineral and slurry nitrogen effects on yield, N uptake, and apparent N-use efficiency of oilseed rape (Brassica napus). Journal of Agricultural Science, Cambridge, Vol. 130, Iss. 02, pp. $165-172$. http://dx.doi.org/10.1017/S0021859697005170

14. Yusuf, R. I., Bullock, D. G. 1993. Effect of several production factors on two varieties of rapeseed in the Central United States. Journal of Plant Nutrition, Vol. 16, Iss. 7, pp. 1279-1288. http://dx.doi.org/10.1080/01904169309364612 